\title{
The Influence Of Kesambi Leaf Extract (Schleichera oleosa) On Proliferation Granulosa Cell Goat Ovarium (Caprus aegagrus HIRCUS) In Vitro
}

\section{Lil Hanifah}

Biology Department Sains and Technology Faculty State Islamic University Maulana Malik Ibrahim of Malang

email:lil.hanifah5@gmail.com

\section{Article Info}

\section{Key word:}

Kesambi leaf extract,

Proliferation,

Granulosa Cells

\section{Article history:}

Submission:04/11/2019

Revised:15/01/2020

Accepted: 04/04/2020

\begin{abstract}
Kesambi (Schleichera oleosa) belonging to the Sapindaceae family has very important phytochemical elements including terpenoids, falvonoids, phenolic acids, betulins, betulin acids and others, so that they have enormous benefits in the process of antimicrobials, antioxidants, anticancer and can be used for the production of biodiesel. One of the potency of antioxidant ability as an antioxidant is due to its phenolic compounds. The presence of antioxidant activity in cells can affect the defense of cell protein membranes, so that the cell's ability to carry out division is optimal. In vitro this is mostly done by adding hormones to culture cell media or natural compound substances to increase cell proliferation. This study is an experimental study using a Complete Random Design (CRD) with 5 treatments and 4 replications as follows: K0: granulosa cells and culture media without treatment $(0 \mu \mathrm{l}), P 1$ : granulosa cells and culture media which were given 1\% porch leaf extract $(30 \mu \mathrm{l})$, P2: granulosa cells and culture media which were given kesambi leaf extract 1.5\% (45 $\mu \mathrm{l})$, P3: granulosa cells and culture media were given 2\% $(60 \mu \mathrm{l})$ kesambi leaf extract and P4: granulosa cells and culture media were given a $2.5 \%(75 \mu l)$ kesambi leaf extract. In this study, there was an influence on the administration of kesambi (Schleichera oleosa) leaf extract to the proliferation of goat ovarian granulosa cells in vitro in the P3 (2\%) treatment ie a dose of $60 \mu \mathrm{l}$. However, it did not have a significant effect on the viability of goat ovarian granulosa cells.
\end{abstract}

Copyright $\Subset 2020$ Universitas Islam Negeri Raden Fatah Palembang. All Right Reserved

\section{Introduction}

Treatment from natural ingredients is currently used by almost $60 \%$ of the world's population. Countries that use natural medicines are not only from developing countries, but also from developed countries where the use of modern medicine is dominant. Traditional treatments from natural ingredients include, among others, medicinal plants, minerals and other organic elements obtained from the extraction of these compounds. (Bathia et.al., 2012). One of the plants which has very important benefits for traditional medicine or healing 
for people in India is kesambi (Schleichera oleosa) (Anuraghi \& Mishra, 2017).

Kesambi (Schleichera oleosa) belongs to the Sapindaceae Family which has very important phytochemical elements including terpenoid, flavonoids, phenolic acid, betulin, betulin acid and so on, which has great benefits in antimicrobial, antioxidant, anticancer and therapeutic processes. biodiesel production (Anuraghi \& Mishra, 2017).

One of the potency of antioxidant ability as an antioxidant is due to its phenolic compounds. Phenolic acid as a therapeutic antioxidant agent contributes to reducing free radicals, reducing exposure to harmful metals, and influencing cell signaling pathways and gene expression (Bhatia, 2012).

Oxidative stress caused by free radicals can occur in body cells including cells that play a role in the reproduction process. The occurrence of oxidative stress on reproductive cells causes malfunctions of important molecules and organelles of cells such as DNA, lipids, proteins and mitochondria. Mitochondria which fail selfrepair mechanism, will trigger the autofagi process of granulosa cells in the follicle. This causes the number of ovarian follicles to decrease and ultimately inhibit the process of folliculogenesis in the ovary (Kandar, 2014).

In ovary, granulosa cells have an important role for reproduction. Because granulosa cells have a function as a provider of oocyte growth nutrients. If the available nutrients from granulosa cells are in sufficient quantities, the oocytes or ova will grow properly. So that the process of maturation or maturation of the ovum will be good too (Sutton et al, 2003 in Waseh, 2016).

Waseh, 2016 also mentioned that proliferation is a process of cell growth which involves active cell division and requires regulation. This cell proliferation aims to replace damaged cells. In vitro this is mostly done by adding hormones to culture cell media or natural compound substances to increase cell proliferation.

\section{Materials and Methods}

This study is an experimental study using the Complete Random Design (CRD) with 5 treatments and 4 replicates. The treatment is as follows:

1. K0: Cells of granulosa and untreated culture media $0 \%$.

2. P1: Granulosa cells and culture media were given $1 \%(30 \mu 1)$ leaf extract.

3. P2: Granulosa cells and culture media were extracted with $1.5 \%(45 \mu 1)$ leaf extract.

4. P3: Granulosa cells and culture media were given $2 \%(60 \mu \mathrm{l})$ leaf extract.

5. P4: Granulosa cells and culture media were given $2.5 \%$ (75 $\mu \mathrm{l})$ of leaf extract.

\section{In vitro Culture Prosses}

Weighed 1.35 gr TCM, 0.37 gr 0.37 gr $\mathrm{NaHCO} 3,0.006$ gr penicillin, $0.01 \mathrm{gr}$ streptomycin and $0.23 \mathrm{gr}$ hepes. All materials were dissolved with $100 \mathrm{ml}$ of sterile deionized water (DI), then homogenized using a magnetic stirrer and filtered with a $0.22 \mu \mathrm{m}$ millipore membrane. Then put in a screw cap bottle and stored at temperature 40 C. Media stock is ready for use.

Goat granulosa cell ovaries were obtained from RPH (Slaughterhouse) Malang. ovaries collected in a collection bottle containing $100 \mathrm{ml}$ of $\mathrm{NaCl}, 0.006 \mathrm{gr}$ pinicillin and $0.01 \mathrm{gr}$ streptomycin that had been prepared previously in a water bath with a temperature of $370 \mathrm{C}$. Under sterile conditions, aspirated by follicular fluid to obtain granulosa cells using $10 \mathrm{ml}$ disposable syringe and a 21-gauge needle. Aspiration results are placed in a centrifuge, $2 \mathrm{ml}$ of TCM 199 0\%, centrifuged at $1000 \mathrm{rpm}$ for 5 minutes, supernatant removed and $2 \mathrm{ml}$ of TCM $1995 \%$ added, centrifuged at $1000 \mathrm{rpm}$ for 5 minutes, removed the supernatant and added $2 \mathrm{ml}$ TCM 199 10\%. After that centrifuged at a speed of $1000 \mathrm{rpm}$ for 5 minutes, then removed the supernatant and taken $100 \mu \mathrm{m}$ of granulosa cell pellets, then put in an incubator at $370 \mathrm{C} \mathrm{5 \%}$. On the 3rd day the media was changed. Then observed on days 3-5 after culture to see the level of cell proliferation. 


\section{Observation of Cell Proliferation}

Observation of cell proliferation was carried out to determine the growth of granulosa cells before and after culture. Granulosa cell proliferation was observed based on the level of cell attachment to the substrate and cell expansion using an Inverted Microscope.

\section{Observation of Cell Viability}

Granulosa cell viability calculation is performed to determine the percentage ratio between living cells and dead cells. Cell viability calculation is done using trypan blue $0.4 \%$. Step in determining viability are as follows: taken cells that have been cultured, discarded the medium then washed with PBS, plus trypsin as much as $1 \mathrm{ml}$. Then incubated for 5 minutes so that the solitary cells, centrifuged with $1 \mathrm{ml}$ PBS added and taken as much as $25 \mu \mathrm{l}$ cell suspension. Then put in a $1.5 \mathrm{ml}$ tube, take $10 \mu \mathrm{l}$ cells and add $10 \mu \mathrm{l}$ trypan blue and then homogenized, take back $10 \mu \mathrm{l}$ cell suspension and trypan blue then put on a disposable glass slide to count on the countess cell automatic cell counter (Invitrogen Thermo Fisher).

\section{Data Analysis}

Data granulosa cell proliferation were analyzed descriptively, while viability was analyzed using ANOVA One Way (Analysis of Varience) statistics. The ANOVA test was used to determine differences of kesambi leaf extract to the viability of goat granulosa cells in vitro.

\section{Results and Discussion}

1. Observation Results of Effect of Giving Kesambi Leaf Extract Against Proliferation of Goat Ovarian Granulosa Cells In Vitro

Based on observations, the giving of kesambi leaf extract with different doses gives different proliferation responses by goat ovarian granulosa cells, according to the following picture:

Figure 1. The Effect of Kesambi Leaf Extract on Goat Ovarian Granulosa Cell Proliferation by In Vitro
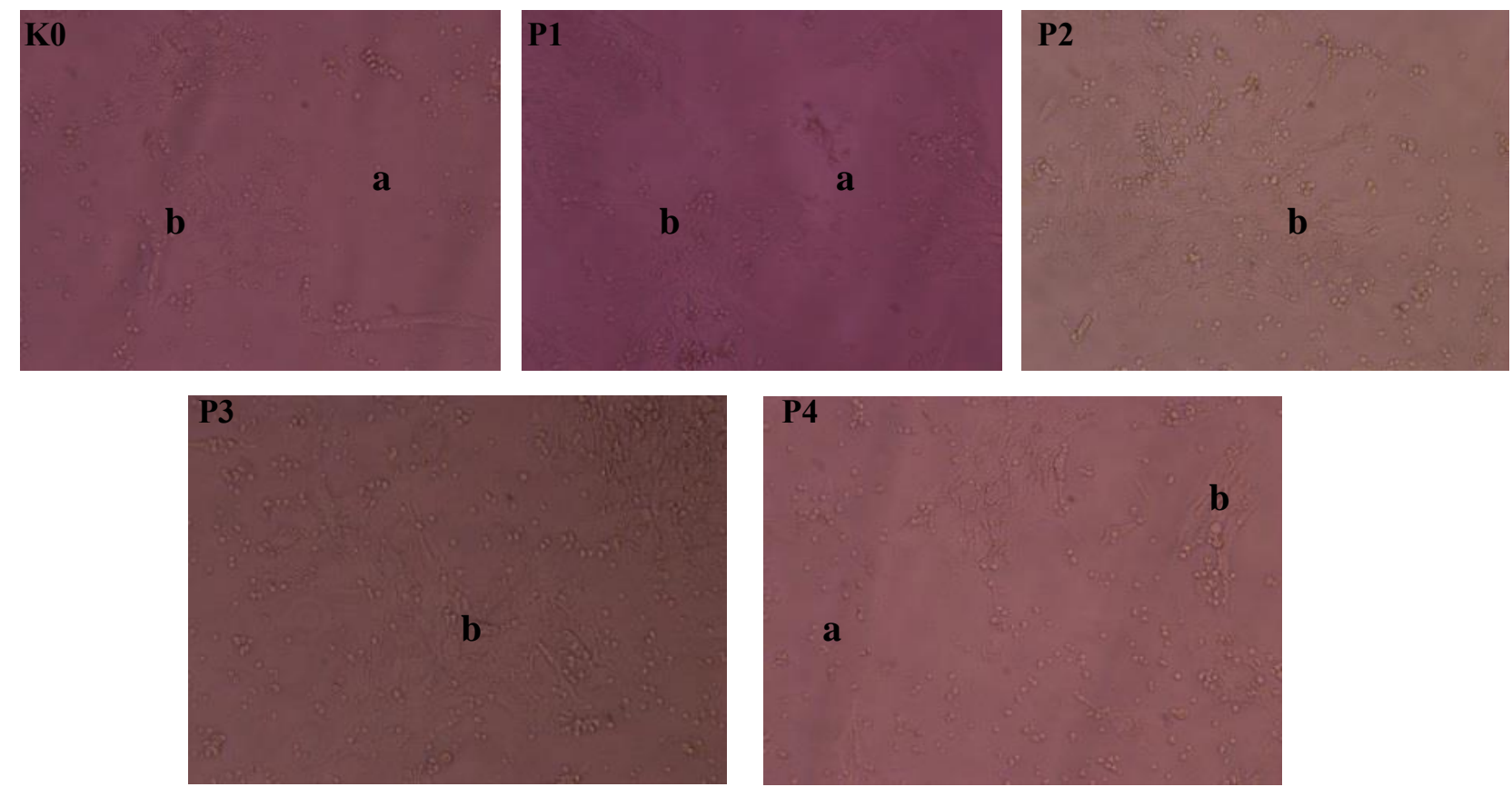

Figure 4.1. Response of Kesambi Leaf Extract Giving Against Goat Ovarian Granulosa Cells on the 3rd day after culture. (P0) Granulosa cell culture without the treatment of kesambi leaf extract (control), (P1) Granulosa cell culture with 1\% kesambi leaf extract treatment, (P2) Granulosa cell culture with the treatment of kesambi leaf extract $1.5 \%$, 
(P3) Cell culture granulosa with $2 \%$ kesambi leaf extract treatment and (P4) Granulosa cell culture with $\mathbf{2 . 5 \%}$ kesambi leaf extract treatment. (a) indicates a single cell, while (b) indicates that the cell has undergone expansion. The image was observed using a Nikon Ti-U Inverted Microscope with a magnification of $10 \times 20$.

Based on these results indicate the level of proliferation in $\mathrm{K} 0$ image has not changed the proliferation significantly, this can be seen from the distribution of cells in the cup which only involves around or $25 \%$ of the plate. In figure P1, correct the cells (a), and some cells that need expansion (b) are more than in image $\mathrm{K} 0$. However, the P1 image is not much different from the $\mathrm{K} 0$ image which is around $30 \%$. In Figure P2, choosing enlarged cells or stretching more and more which is also increased by the proliferation rate which also increases in the range of 40$50 \%$. P3 also shows cells that have expanded more and more with a proliferation rate of around $45-55 \%$. While for P4 images show a better proliferation rate of $35 \%$, cells still increase expansion or stretching (b)

From the results of this study indicate that giving of kesambi leaf extract affects the proliferation of goat ovarian granulosa cells in vitro. Antioxidants in kesambi leaves include flavonoids, polyphenols and tannins. The three compounds are phenol compounds, which are compounds with -OH groups bonded to aromatic carbon rings. Flavonoids function as effective antioxidants by giving hydrogen atoms to free radicals to form free radical products themselves in this compound. The free radical product of these compounds is resonant stabilized due to conjugated double bonds and is therefore not reactive compared to most other free radicals (Rahmawati, 2014).

The mechanism of antioxidants in neutralizing free radicals is done by giving one electron to become a more stable compound or termination reaction and radical reactions end or oxidative stress does not occur in cells (Parwata 2016). When free radicals do not occur in the cell, then the cell will be stable and can do the division and growth properly.

Some phytosterols can also act as antioxidants in cells. Phytosterols (plant sterols) are flavonoid, triterpenes which are important structural components of plant membranes, and free phytosterols function to stabilize the phospholipid bilayer in plant cell membranes as well as cholesterol in animal cell membranes (Moreau, 2002). Free radicals in cells can produce lipid peroxides which can ultimately cause cell death and the release of MDA and HNE (Fatmawati, 2012). So that this phytosterol can be an antioxidant on free cell exposure, including reproductive cells.

Some of the active ingredients contained in phytosterols can inhibit the oxidation of hydrogen release from antioxidants, release electrons from antioxidants, add fat in aromatic rings to antioxidants, add complex compounds between fats and aromatic rings from antioxidants (Ketaren, 1986 in Subandi, 2018). From this reaction the cells in the ovary are not easily damaged, so cells in the ovarian tissue can work optimally.

Based on this study the administration of kesambi leaf extract in P3 (2\%) $60 \mu$ l treatment dose, that is, the dose gives the effect of cell proliferation which is increasing compared to other treatments. Increased proliferation and expansion of these cells is an indicator that the administration of kesambi leaf extract to goat ovarian granulosa cells makes these cells capable of maintaining their condition into stable cells.

\section{The Effect of Giving Kesambi Leaf Extract on Viability of Goat Ovarian Granulosa Cells In Vitro}

Observation of goat ovarian granulosa cell viability in this study aims to determine the level of cell survival after administration of kesambi leaf extract in culture media. This can be seen in the table below below: 
Table 1. Effect of Giving Kesambi Leaf Extract Against Viability of Goat Ovarian Granulosa Cells

\begin{tabular}{cc}
\hline Treatment & $\begin{array}{c}\text { Average Viabilitias } \\
(\%) \pm \text { SD }\end{array}$ \\
\hline K0 $(0 \%) 0 \mu 1$ & $16,33 \pm 0,92$ \\
P1 $(1 \%) 30 \mu 1$ & $36 \pm 4,39$ \\
P2 $(1,5 \%) 45 \mu 1$ & $55 \pm 8,50$ \\
P3 $(2 \%) 60 \mu 1$ & $25 \pm 3,79$ \\
P4 $(2,5 \%) 75 \mu 1$ & $34,33 \pm 12,7$ \\
\hline
\end{tabular}

Table 1 shows the viability of granulosa cells in the treatments K0, P1 (1\%), P2 $(1.5 \%), \mathrm{P} 3(2 \%)$ and P4 $(2.5 \%)$ are as follows: $16.33 \pm 0.92 \%, 36 \pm 4.39 \%, 55 \pm$ $8.50 \%, 25 \pm 3.79 \%$ and $34.33 \pm 12.7 \%$.

The highest level of viability of granulosa cells was highest in P2 dose 1.5\% (45 $\mu \mathrm{l})$ compared with other treatments including controls. This shows that giving a dose of kesambi leaf extract of $45 \mu \mathrm{l}$ provides the highest level of viability and not the highest dose of $75 \mu \mathrm{l}$. This shows that the increase in the viability of granulosa cells due to metabolic processes in granulosa cells occurs well under optimal conditions. In the metabolic process ATP will be produced which will be used by cells to proliferate and differentiate so that the viability of cells that are able to survive is greater (Kalanjati, 2006).

Observation of the results of granulosa cell viability was then analyzed using ANOVA (Analysis of Variance) One Way statistics on the SPSS v16.0 program shown in the following table:

Table 2. Summary of One Way ANOVA (Analysis of Variance) Effect of Giving Kesambi Leaf Extract Against Viability of Goat Ovarian Granulosa Cells In Vitro

\begin{tabular}{lrrrrrr}
\hline & Sum of Squares & df & Mean Square & F & \multicolumn{1}{c}{ Sig. } \\
\hline Between Groups & 73,866 & 4 & 18,466 &, 342 &, 844 \\
Within Groups & 540,038 & 10 & 54,004 & & \\
Total & 613,903 & 14 & & & \\
\hline
\end{tabular}

In table 2 shows the $\mathrm{F}$ count $<$ from the $\mathrm{F}$ table that is $0.342<0.844$. It can be concluded that $\mathrm{H} 0$ is accepted and $\mathrm{H} 1$ is rejected, which means that the administration of kesambi leaf extract does not significantly affect the viability of goat ovarian granulosa cells in vitro. This is partly because the dose of kesambi leaf extract has a range that is too low for each other so that between treatments it does not show a significant effect when tested using statistics.

Other causes can also be caused by the selective nature of kesambi leaf extract which can induce apoptosis in abnormal cells (tumors) without injuring normal cells, so that cell viability in normal cells is maintained. So in the treatment of kesambi extract administration to normal cells the results are not much different from the control treatment (Jannah, 2019).

\section{Conclusions}

Based on the results of the study it can be concluded that: Giving kesambi leaf extract (Schleichera oleosa) gives an influence on the proliferation of ovul granulosa cell cells (Caprus aegagrus) in vitro. However, it does not affect the viability of goat ovarian granulosa cells. while the optimal dose that gives the effect of giving kesambi leaf extract (Schleichera oleosa) to the proliferation of goat ovarian granulosa cells (Caprus aegagrus) in vitro is on the treatment of P3 $2 \%$ dose which is $60 \mu 1$.

\section{References}

Anuraghi, Jay., Mishra, RP. 2017. Ethnomedicinal study of Schleichera oleosa among the tribals of Satna (M.P.). International Journal of Applied Research, 3(3): 672-67.

Bathia, Harsh., Kaur, Jaspreet., Nandi, Shreya., Gurnani, Virnita., Chowdury, Anushua., Hemalatha, P., Vashistha, 
Amit., Rathi, Brijesh. 2012. A Review on Schleichera oleosa: Pharmacological and Environmental Aspects. Elsevier Journal of Pharmacy Research 6: 224-229.

Fatmawati, Khotma et. Al. 2012. Efek Proteksi Kombinasi Minyak Wijen (Sesame Oil) dengan $\alpha$-Tocopherol terhadap Steatosis melalui Penghambatan Stres Oksidatif pada Tikus Hiperkolesterolemia. The Journal of Experimental Life Science. Vol 2: 2

Hamny, S. Agungpriyono, I. Djuwita. 2010. Karakteristik Histologi Perkembangan Folikel Ovarium Fase Luteal Pada Kancil (Tragulus javanicus). Indonesian Journal of Veterinary Science \& Medicine. Volume II No.1

Hati, Rafika. 2016. Pengaruh Ekstrak Ethanol Daun Sisik Naga (Pyrrosia pilosellaides) Terhadap Tingkat Kematangan Folikel Ovarium Kambing (Capra Aegagrus Hircus) Secara In Vitro. Skripsi. UIN Maulana Malik Ibrahim Malang. Malang

Heyne, K. 1987. Tumbuhan Berguna Indonesia. Jilid I dan II. Terj. Badan Libang Kehutanan. Cetakan I. Koperasi Karyawan Departemen Kehutanan Jakarta Pusat

Ismaya. 2014. Bioteknologi Inseminasi Buatan Pada Sapi dan Kerbau (Biotechnology Of Artificial Insemination on Cattle And Buffalo). Gadjah Mada University Press. Yogyakarta

Jubidin, Syafiah N. 2013. Penampilan Reproduksi Kambing Boer (Studi Kasus di Pusat Bioteknologi Perkhidmatan Haiwan dan Perusahaan Ternak (JPHPT) Keningau, Sabah, Malaysia). Skripsi. Fakultas Kedokteran Hewan Institut Pertanian Bogor. Bogor

Kalanjati, Woro. 2006. Perbedaan Konfluensitas dan Viabilitas Sel Kultur Primer Sel Fibroblas Dari Jaringan Daun Telingan Rusa Bawean (Axis kuhlii) Pada Medium TCM 199 dan
MEM. Skripsi. Universitas Airlangga. Surabaya

Kandar, Patricia. S. 2014. Pemberian Alpha Lipoid Acid Per Oral Menghambat Gangguan Folikulogenesis Pada Mencit (Mus musculus) BalB/c Betina yang Dipapar Asap Rokok. Tesis. Universitas Udayana. Denpasar

Khumairoh Ika, Puspitasari I. 2016. Kultur Sel. Review Artikel. Jurnal Farmaka. Volume 14: 2

Moreau, Robert, et.al. 2002. Phytosterols, phytostanols, and their conjugates in foods: structural diversity, quantitative analysis, and health-promoting uses. Review. SicienceDirect. Vol 41:6

Parwata, I. 2016. Antioksidan. Bahan Ajar. Pasca Sarjana Universitas Udayana. Denpasar

Pawoko, Endro. 2009. Pengaruh Tahapan Proses Esterifikasi, Transesterifikasi Dan Netralisasi Terhadap Karakteristik Biodiesel Dari Biji Kesambi. Skripsi. Institut Pertanian Bogor. Bogor

Rahmawati, Muti'ah. 2014. Potensi Ekstrak Daun Widuri (Calotropis gigantea) Sebagai Obat Antikanker Fibrosarkoma. UIN-Maliki Press. Malang

Rejeki, T.R., Harjana Tri, Sukiya. 2017. Pengaruh Ekstrak Daun Kenari (Canarium indicum, 1.) Terhadap Perkembangan Folikel Ovarium Tikus Putih Betina (Rattus norvegicus, 1.). Jurnal Prodi Biologi Vol 6 No 3: 194

Sitorus, Mega Sari. 2013. Imunoekspresi Ki67 Pada Tumor Payudara Tikus Wistar Yang Diinokulasi Tumor Terinduksi Benzo(A) Pyrene Dan Diberikan Ekstrak Daun Sirsak. Thesis. Universitas Sumatera Utara. Medan

Subandi, Imam. 2018. Profil Protein Ovarium Tikus Putih (Rattus norvegicus) Betina Setelah Pemberian Ekstrak Etanol Daun Sisik Naga. Skripsi. UIN Maulana Malik Ibrahim Malang. Malang

Suita, Eliya. 2016. Seri Teknologi Perbenihan Tanaman Hutan Kesambi 
(Schleichera oleosa MERR.). Balai Penelitian Teknologi Perbenihan Tanaman Hutan Badan Penelitian dan Pengembangan Kehutanan Kementerian Hutan. Bogor

Waseh, Laneng. 2016. Pengaruh Lama Paparan Murottal Surat Al-Fatihah Terhadap Proliferasi Sel Granulosa Kambing (Capra Aegagrus Hircus) Secara In Vitro. Skripsi. UIN Maulana Malik Ibrahim Malang. 